\title{
Neuromuscular presentations in patients with COVID-19
}

\author{
Vimal Kumar Paliwal ${ }^{1}$ (D) $\cdot$ Ravindra Kumar Garg $^{2}$ (D) $\cdot$ Ankit Gupta $^{1} \cdot$ Nidhi Tejan $^{3}$
}

Received: 7 July 2020 / Accepted: 1 September 2020 / Published online: 15 September 2020

(C) Fondazione Società Italiana di Neurologia 2020

\begin{abstract}
COVID-19 is caused by the coronavirus SARS-CoV-2 that has an affinity for neural tissue. There are reports of encephalitis, encephalopathy, cranial neuropathy, Guillain-Barrè syndrome, and myositis/rhabdomyolysis in patients with COVID-19. In this review, we focused on the neuromuscular manifestations of SARS-CoV-2 infection. We analyzed all published reports on SARS-CoV-2-related peripheral nerve, neuromuscular junction, muscle, and cranial nerve disorders. Olfactory and gustatory dysfunction is now accepted as an early manifestation of COVID-19 infection. Inflammation, edema, and axonal damage of olfactory bulb have been shown in autopsy of patients who died of COVID-19. Olfactory pathway is suggested as a portal of entry of SARS-CoV-2 in the brain. Similar to involvement of olfactory bulb, isolated oculomotor, trochlear and facial nerve has been described. Increasing reports Guillain-Barrè syndrome secondary to COVID-19 are being published. Unlike typical GBS, most of COVID-19-related GBS were elderly, had concomitant pneumonia or ARDS, more prevalent demyelinating neuropathy, and relatively poor outcome. Myalgia is described among the common symptoms of COVID-19 after fever, cough, and sore throat. Duration of myalgia may be related to the severity of COVID-19 disease. Few patients had muscle weakness and elevated creatine kinase along with elevated levels of acute-phase reactants. All these patients with myositis/rhabdomyolysis had severe respiratory complications related to COVID-19. A handful of patients with myasthenia gravis showed exacerbation of their disease after acquiring COVID-19 disease. Most of these patients recovered with either intravenous immunoglobulins or steroids.
\end{abstract}

Keywords SARS-CoV-2 · COVID-19 · Coronavirus · Anosmia · Ageusia · Guillain-Barrè syndrome $\cdot$ Myositis · Rhabdomyolysis

The COVID-19 pandemic is caused by SARS-CoV-2, a member of the Coronavirinae subfamily. The coronaviruses are classified in four genera: alpha, beta, gamma, and delta coronaviruses [1]. The world has seen three large pandemics

Vimal Kumar Paliwal

dr_vimalkpaliwal@rediffmail.com

Ravindra Kumar Garg

garg50@yahoo.com

Ankit Gupta

drankitgupta90@gmail.com

Nidhi Tejan

getnids@gmail.com

1 Department of Neurology, Sanjay Gandhi Postgraduate Institute of Medical Sciences, Lucknow, UP 226014, India

2 Department of Neurology, King George Medical University, Lucknow, UP, India

3 Department of Microbiology, Sanjay Gandhi Postgraduate Institute of Medical Sciences, Lucknow, UP 226014, India in the last 2 decades. The first pandemic originated in Guangdong, China (2002-2003) caused by SARS-CoV-1, and the second pandemic originated in Saudi Arabia (2012), caused by MERS CoV [2-4]. Both pandemics produced severe acute respiratory syndrome (SARS) in thousands of people and produced case fatality rate of $9.6 \%$ and $34.4 \%$, respectively [5]. The current pandemic is caused by novel coronavirus named as SARS-CoV-2 that originated in Wuhan, China, in December 2019. As of July 2020, COVID-19 has affected 14.3 million people and produced more than six hundred thousand deaths. All three viruses that produced these three pandemics are beta coronaviruses and share a homologous genomic sequence. The SARS-CoV-2 has a higher affinity for angiotensin-converting enzyme receptor 2 (ACE-2) that is expressed on endothelial cells and neurons. This explains a higher neuro-invasive capacity of SARS-CoV-2 as compared with previous coronaviruses [6].

A number of neurological manifestations of SARS-CoV-2 have been reported. These include encephalitis, acute disseminated encephalomyelitis (ADEM), encephalopathy, steroidresponsive encephalopathy, posterior reversible encephalopathy 
syndrome (PRES), and meningitis. The neuromuscular manifestations like hyposmia/ageusia, ophthalmoparesis, facial paresis, Guillain-Barré syndrome, symmetrical neuropathy, criticalillness myopathy and neuropathy, myalgia, myositis, and rhabdomyolysis have also been described in patients secondary to COVID-19. In this review, we focused on the neuromuscular manifestation of SARS-CoV-2 infection.

\section{Methods}

We analyzed all published reports on COVID-19-associated neuromuscular manifestations. We performed an extensive search of PubMed, Google Scholar, Scopus, and preprint databases (medRxiv and bioRxiv). We identified isolated case reports, case series, and cohort studies. We used search terms, "COVID-19 and Guillain-Barré syndrome, hyposmia, myositis, rhabdomyolysis, neuropathy" and "SARS-CoV-2 and Guillain-Barré syndrome, hyposmia, myositis, rhabdomyolysis, neuropathy". Full-text articles were acquired from journals' websites. We analyzed demographic, clinical, CSF, and neuroimaging characteristics of patients presenting with COVID-19-related peripheral nervous system manifestations. We also discuss the pathogenesis of COVID-19-associated neuropathy and muscle involvement. The last search was done on 2 July 2020.

\section{Search results}

We identified 96 studies of COVID-19-related myalgia. After exclusion of descriptive reviews, data in other than English language, and duplicate studies, we selected 13 studies and 2 meta-analysis comprising of 10 and 55 studies, respectively (Table 1) [7-21].

Similarly, we identified 8 case reports (9 patients) with keywords COVID-19 and myositis/rhabdomyolysis (Table 2) [22-29].

Two reports described exacerbation of myasthenia gravis in six patients secondary to COVID-19 infection [30, 31].

We identified 34 reports comprising 39 patients with Guillain-Barrè syndrome and five patients with Miller-Fisher syndrome (Tables 3 and 4) [32-65].

In addition to GBS and MFS, we also included three reports of six patients who developed symmetrical or asymmetrical neuropathy (Table 5) [66-68].

We identified 2 meta-analyses of 24 and 21 studies/case reports respectively that described patients with olfactory/ gustatory dysfunction [69, 70]. In addition, we describe 11 studies that evaluated olfactory/gustatory dysfunction in COVID-19 patients (Table 6) [71-81].

We also included 5 reports (6 patients) of isolated cranial neuropathy in COVID-19 patients (Table 6) [82-87].

\section{Myalgia}

A meta-analysis of clinical characteristics by Long-quan Li et al. (10 studies, 1995 patients, published between December 2019 and February 2020) showed that prevalence of myalgia was $35.8 \%$ (range 11 to $50 \%$ ). Frequency of other symptoms was fever (88.5\%), cough (68.6\%), expectoration (28.2\%) and dyspnoea (21.9\%). Less common symptoms were dizziness, diarrhoea, nausea, and vomiting. They found a fatality rate of $5 \%$ and discharge rate of 52\% in COVID-19 patients [10]. Another meta-analysis (55 studies, 8697 patients, published between 1 January 2020 and 16 March 2020) showed myalgia in $21.9 \%$ COVID-19 patients. Other common symptoms were fever $(78.4 \%)$, cough $(58.3 \%)$, fatigue $(34 \%)$, expectoration (23.7\%), anorexia (22.9\%), chest tightness (22.9\%), and dyspnoea $(20.6 \%)$. Patients diagnosed before January 31 had higher prevalence of fever and cough. The authors concluded that as the pandemic grew, the prevalence of atypical symptoms increased [15]. In a study of olfactory and gustatory function in COVID-19 patients by Lechien et al., more than 50\% patients had myalgia [76]. In a retrospective study by Zhang et al., muscle ache was one of the independent predictors for unimprovement in patients with COVID-19. The other independent predictors were being male, severe COVID-19 condition, expectoration, and decreased albumin at admission [87]. In a cohort of pregnant patients, the frequency of constitutional symptoms of COVID-19 infection was similar to the general population. The study did not find any vertical transmission of COVID-19 infection [88]. In a study comparing the clinical features of SARS-CoV-1 and COVID-19 infection, fever and cough were equally prevalent in both infections but the myalgia and diarrhoea were less common in COVID-19 as compared with SARS-CoV-1 [89]. In a study of 1420 European patients with COVID-19, elderly patients were more likely to have myalgia, fatigue, and fever as compared with younger patients who had higher propensity to acquire symptoms related to ear, nose, and throat [13]. As compared with COVID-19-negative patients, COVID-19-positive patients with respiratory illness reported longer symptom duration (median 7 vs. 3 days), higher prevalence of fever ( $82 \%$ vs. $44 \%$ ), fatigue ( $85 \%$ vs. $50 \%$ ), and myalgias (61\% vs $27 \%$ ) [90]. Myalgia persisted at the median time of 23 days of cessation of viral shedding. The other symptoms that persisted at the time of cessation of viral shedding were cough, anosmia, ageusia, and sore throat [91].

\section{Myositis/rhabdomyolysis}

Nine patients (age range 16 to 88 years, all males) with COVID-19-related myositis/rhabdomyolysis were reported [22-29]. Eight patients presented with generalized or limb weakness. Myalgias were present in four patients. One patient who did not have muscle weakness presented with myalgia, 
Table 1 Studies showing prevalence of myalgia and other presenting symptoms in patients with COVID-19

\begin{tabular}{|c|c|c|c|}
\hline Author/year & Meta-analysis/study & $\begin{array}{l}\text { Prevalence of } \\
\text { myalgia }(\%)\end{array}$ & $\begin{array}{l}\text { Other presenting } \\
\text { symptoms }\end{array}$ \\
\hline Huang et al./Feb, 2020 [7] & Study $(N=41)$ & 44 & $\begin{array}{c}\text { Fever } 98 \% \text {, cough } 76 \% \text {, dyspnoea } 55 \% \text {, expectoration } 28 \% \text {, } \\
\text { headache } 8 \% \text {, haemoptysis } 5 \% \text {, diarrhoea } 3 \%\end{array}$ \\
\hline $\mathrm{Xu}$ et al./Feb, 2020 [8] & Study $(N=62)$ & 52 & $\begin{array}{l}\text { Fever } 77 \% \text {, cough } 81 \% \text {, expectoration } 56 \% \text {, headache } \\
34 \% \text {, diarrhoea } 8 \% \text {, dypnoea } 3 \%\end{array}$ \\
\hline Liu et al./March, 2020 [9] & Study ( $N=30 \mathrm{HCW}$ with pneumonia) & 70 & $\begin{array}{l}\text { Cough } 83.33 \% \text {, fever } 76.67 \% \text {, headache } 53.33 \% \text {, } \\
\text { GI symptoms } 30 \% \text {, dypnoea } 46.67 \%\end{array}$ \\
\hline Li et al./March, $2020[10]$ & Meta-analysis $(N=1995)$ & 35.8 & $\begin{array}{l}\text { Fever } 88.5 \% \text {, cough } 68.6 \% \text {, expectoration } \\
28.2 \% \text {, Dyspnoea } 21.9 \% \text {, headache } 12.1 \%\end{array}$ \\
\hline Wang et al./Apr, 2020 [11] & Study $(N=80, \mathrm{HCW})$ & 23.75 & $\begin{array}{l}\text { Fever } 81.25 \% \text {, cough } 58.75 \% \text {, fatigue } 35 \% \text {, } \\
\text { expectoration } 23.75 \% \text {, diarrhoea } 18.75 \%\end{array}$ \\
\hline Wei et al./Apr, 2020 [12] & Study $(N=14$, pneumonia) & 100 & Fever $86 \%$, dry cough $71 \%$ \\
\hline Lechien et al./Apr, 2020 [13] & Study $(N=1420)$ & 62.5 & $\begin{array}{l}\text { Headache } 70.3 \% \text {, anosmia } 70.2 \% \text {, nasal } \\
\text { obstruction } 67.8 \% \text {, cough } 63.2 \% \text {, asthenia } 63.3 \% \text {, } \\
\text { rhinorrhoea } 60.1 \% \text {, gustatory dysfunction } \\
54.2 \% \text {, sore throat } 52.9 \% \text {, fever } 45.4 \%\end{array}$ \\
\hline Lai et al./May, 2020 [14] & Study $(N=110 \mathrm{HCW})$ & 45.5 & Fever $60.9 \%$, cough $56.4 \%$, sore throat $50 \%$ \\
\hline Zhu et al./May, 2020 [15] & Meta-analysis & 21.9 & $\begin{array}{l}\text { Fever } 78.4 \% \text {, cough } 58.3 \% \text {, fatigue } 34 \% \text {, } \\
\text { expectoration } 23.7 \% \text {, anorexia } 22.9 \% \text {, } \\
\text { chest tightness } 22.9 \% \text {, dyspnoea } 20.6 \%\end{array}$ \\
\hline Lapostolle et al./May 2020 [16] & Study $(N=1487)$ & 57 & $\begin{array}{l}\text { Fever } 92.5 \% \text {, dry cough } 94 \% \text {, headache } 55 \% \text {, } \\
\text { asthenia } 28 \% \text {, ageusia } 28 \% \text {, chest pain } 21 \% \text {, } \\
\text { hemoptysis } 3 \%\end{array}$ \\
\hline Chen et al./June, 2020 [17] & Study $(N=38$, fatalities $)$ & 15.79 & $\begin{array}{l}\text { Fever } 65.78 \% \text {, cough } 42.10 \% \text {, dyspnoea } \\
\quad 60.52 \% \text {, chest tightness } 26.31 \%\end{array}$ \\
\hline Korkmaz et al./June, 2020 [18] & Study $(N=80$, children) & 19 & Fever $(58 \%)$, cough $(52 \%)$ \\
\hline Reilly et al./June, 2020 [19] & Study $(N=14)$ & 67 & Dyspnea (77\%), fatigue (100\%), diarrhoea (67\%) \\
\hline Gaur et al./July, 2020 [20] & Study $(N=26)$ & 38.46 & $\begin{array}{l}\text { Fever }(61.54 \%) \text {, sore throat }(53.84 \%) \text {, cough } \\
\quad(42.3 \%), \text { dyspnea }(23.07 \%)\end{array}$ \\
\hline Aggarwal et al./July, 2020 [21] & Study $(N=32$, ARDS $)$ & 43.75 & Dyspnea $(90 \%)$, cough $(84.4 \%)$, fever $(68 \%)$ \\
\hline
\end{tabular}

$A R D S$ acute respiratory distress syndrome, $H C W$ health care worker

fever, and dyspnoea [26]. One patient presented with repetitive muscle twitching along with tingling and numbness in the legs [28]. Only one patient had cola-coloured urine [29]. Three patients passed red blood cells in the urine. All patients had elevated CPK levels [28, 29]. One patient who presented with cola-coloured urine had most elevated CPK level of 427,656 IU/L. All patients had elevated levels of CRP, $\mathrm{LDH}$, and serum ferritin. Six patients had abnormalities on chest imaging like ground-glass opacities, pneumonia, pleural effusion, or multifocal opacities. Two patients required mechanical ventilation $[22,29]$. Five patients improved with conservative management.

In addition to myositis and rhabdomyolysis, there is a report of six COVID-19 patients with critical-illness myopathy. All six patients had acute flaccid quadriparesis. Electrophysiological tests revealed a myopathic pattern. They had mildly elevated creatine kinase and all patients had a good outcome [92]. Cachexia and sarcopenia have also been described in patients affected by COVID-19 [93].

\section{Myasthenia gravis}

There are no reports of de-novo occurrence of myasthenia gravis secondary to COVID-19. However, there are two reports of 5 and 1 patients respectively (age range 42-90 years, 4 females) of COVID-19 infection-related exacerbation of the pre-existing myasthenia gravis [30,31]. Five patients had antiacetylcholine receptor antibody-positive myasthenia gravis whereas one patient had muscle-specific kinase (MuSK)-positive myasthenia gravis. All patients had exacerbation of myasthenic symptoms after sore throat, fever, cough, and shortness of breath in variable combination. Two patients required mechanical ventilation. Steroids were continued in 4 patients. Two patients received intravenous immunoglobulins. Two patients were taking mycophenolate mofetil that was transiently stopped in view of COVID-19 infection. MMF was resumed in both patients after discharge from the hospital. Five patients improved, and one patient was on mechanical ventilator at the time of publication of the report. 


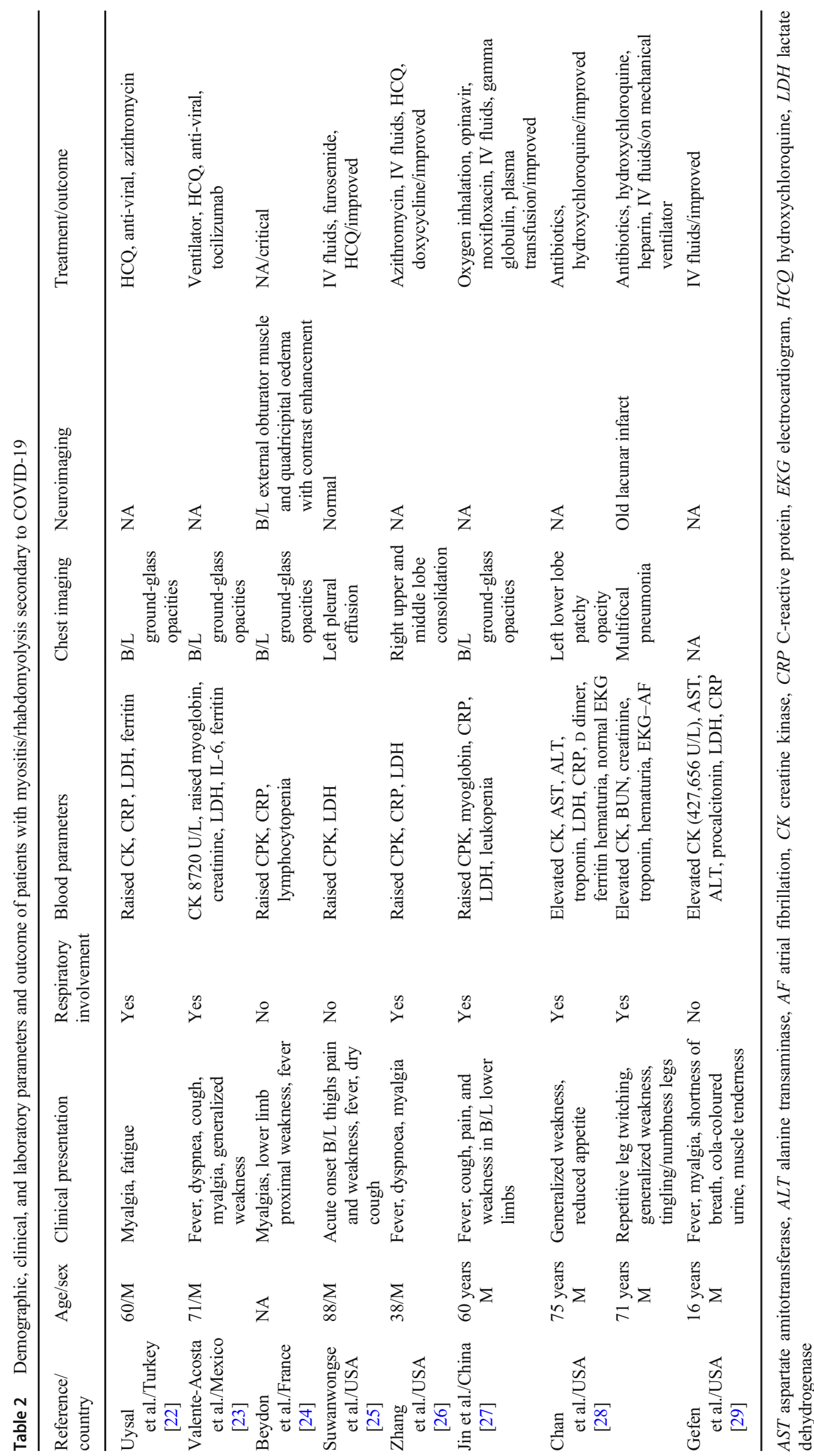




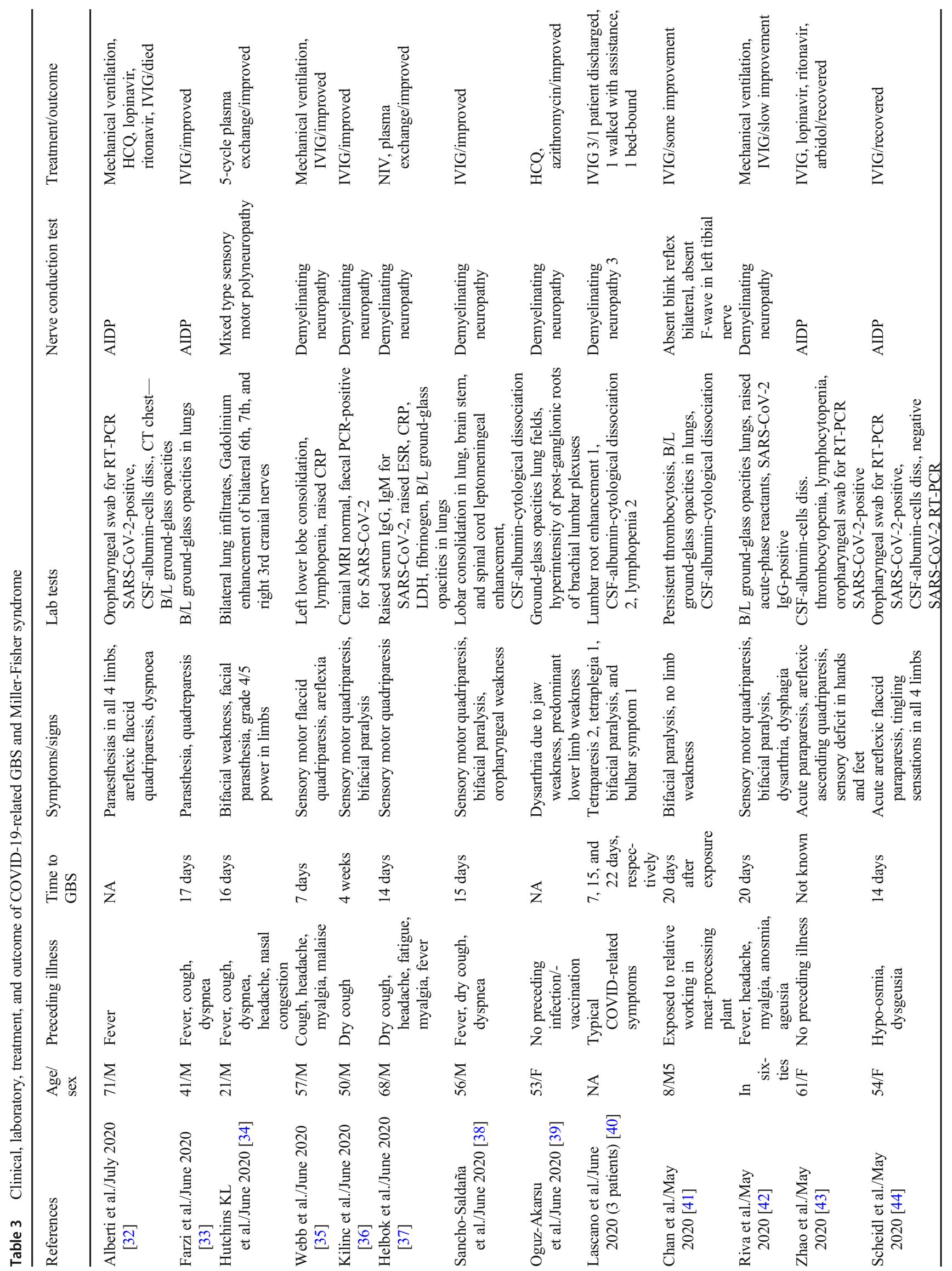




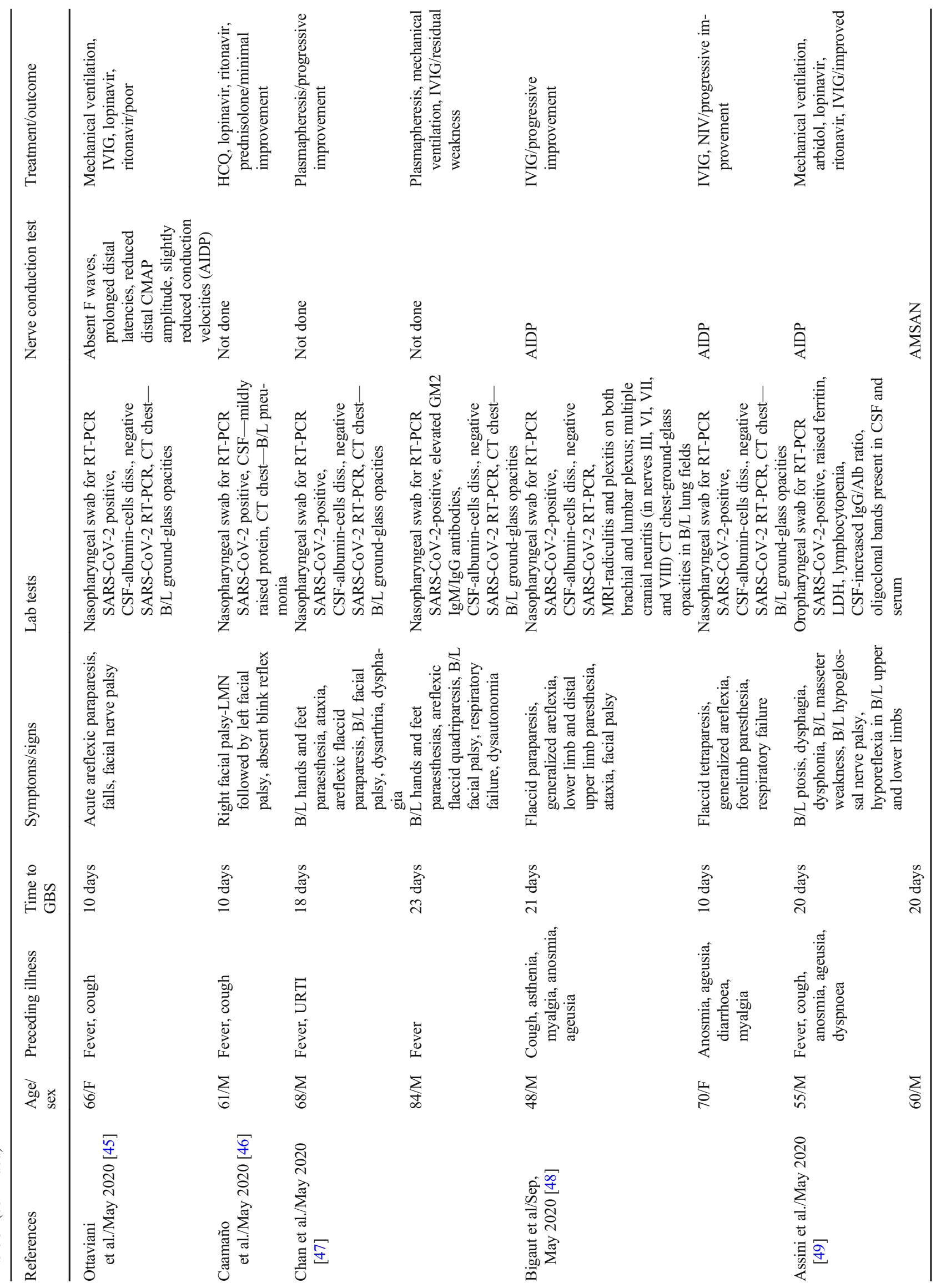




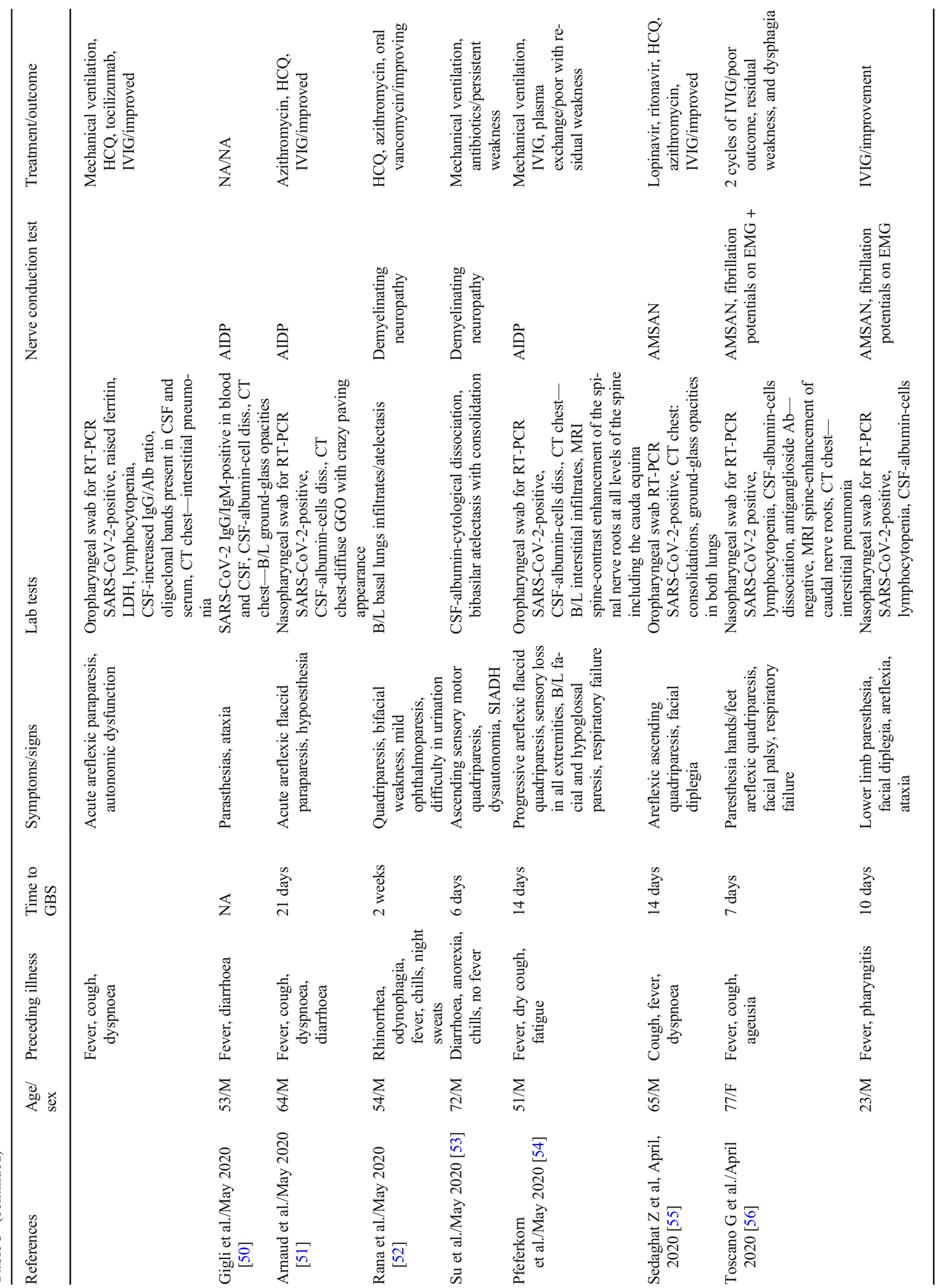




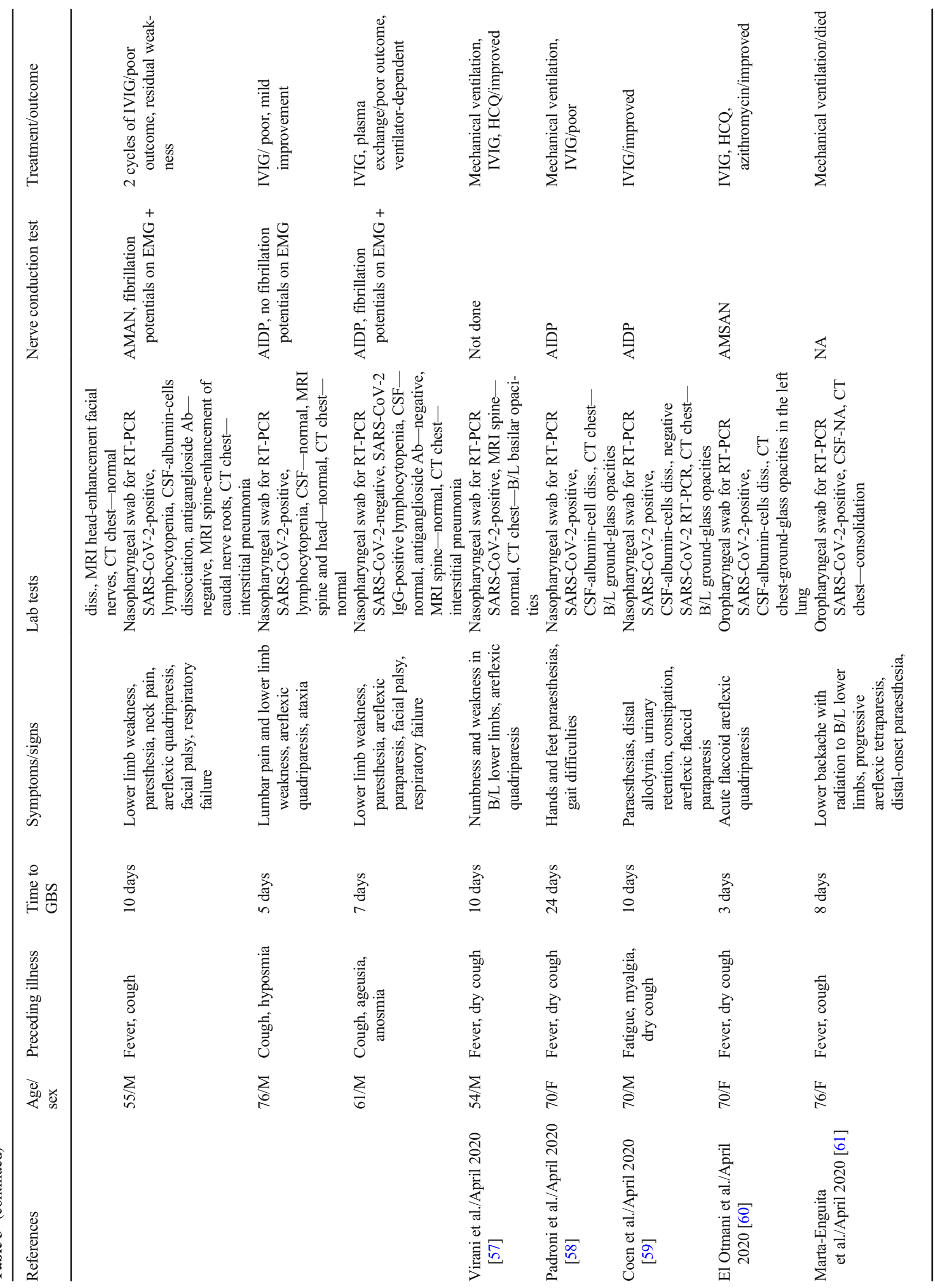




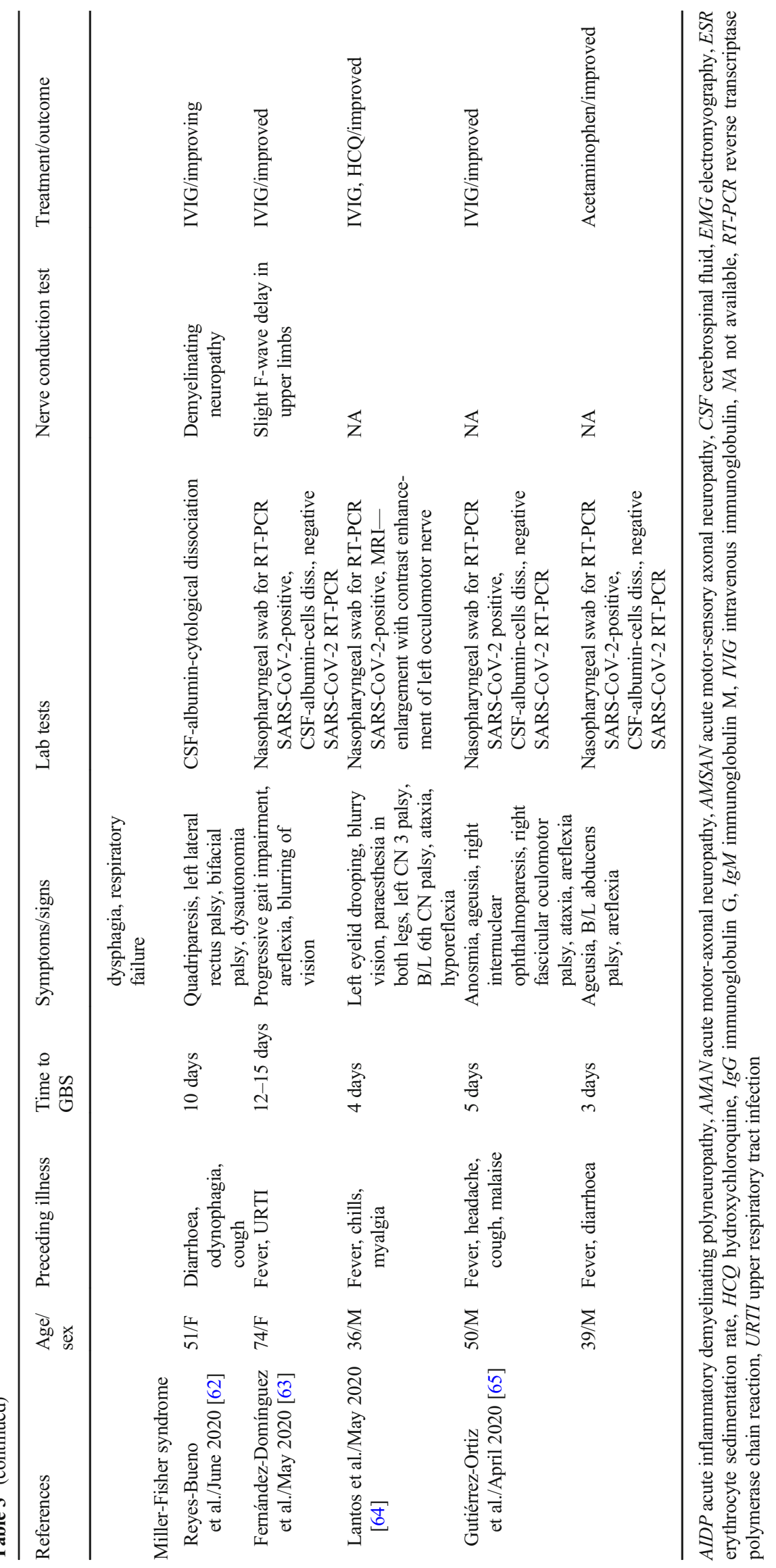


Table 4 Frequency of various demographic, clinical, and electrophysiological features and good outcome in patients with COVID-19-related GBS

\begin{tabular}{ll}
\hline Feature & Frequency \\
\hline Number & 39 \\
Age (data available in 36 patients) & $\begin{array}{c}21-85 \text { years, mean }=60.55, \\
\text { median }=61, \text { mode }=70\end{array}$ \\
Males (data available in 35 patients) & $26(74.28 \%)$ \\
Hyposmia/ageusia & $6(15.4 \%) / 7(17.9 \%)$ \\
Time to onset of GBS (data available in 35patients) & $3-28$ days, mean $=13.91$ days, \\
Bifacial paralysis & median $=14$, mode $=10$ \\
Other cranial neuropathies & $18(46.15 \%)$ \\
Respiratory involvement & $9(23.07 \%)$ \\
Demyelinating/axonal (data available in 32 patients) & $17(43.58 \%)$ \\
Outcome (data available in 38 patients) & $24(75 \%) / 7(22 \%)$
\end{tabular}

\section{Guillain-Barrè syndrome and Miller-Fisher syndrome}

Recently, 39 patients with GBS and 5 patients with MFS secondary to COVID-19 were published. Most of the reports were from China, Italy, and the USA. The demographic profile, frequency of clinical features, electrophysiological features, and good outcome are described in Table 3. GBS and MFS were more frequent in elderly people. Time to onset of GBS/MFS ranged from 3 days to 4 weeks of onset ofCOVID19 symptoms. Majority of patients had para-infectious and minority had post-infectious GBS/MFS. Upper respiratory tract symptoms were the usual preceding symptoms. Hyposmia and ageusia were distinctive features seen in COVID-19 patients unlike the typical GBS where these olfactory symptoms are not seen. Most patients had ascending or lower limb areflexic weakness that later on progressed and involved bifacial weakness and other cranial neuropathies. Unlike typical GBS, respiratory failure secondary to lung involvement was common in GBS patients secondary to COVID-19. Majority of patients had severe demyelinating type of neuropathy. CSF-albumin-cytological dissociation was frequently noticed. SARS-CoV-2 RT-PCR was not detected in the CSF of the patients subjected to the test. Most patients with lung pathologies required mechanical ventilation and had a poor outcome in the form of either prolonged ventilatory stay, residual weakness, or death.

Five patients with MFS (age range 36-74 years, 3 males) presented with preceding upper respiratory symptoms (2 patients) and diarrhoea (1 patient). All three patients had gait difficulty, ataxia, and areflexia. One patient had visual blurring and 2 patients had ophthalmoparesis. Two patients had preceding ageusia/hyposmia. Four patients received intravenous immunoglobulin. All five patients improved.

\section{Neuropathy}

Three reports of 6 patients with COVID-19-related neuropathy were published [66-68]. Authors claimed that the neuropathy in their patients was different from GBS. Ghiasvand et al. reported a 68 -year-old female with symmetrical lower motor neuron quadriparesis after an initial upper respiratory involvement. Due to respiratory involvement, patient died and electrophysiological tests could not be performed [66]. Abdelnour et al. reported a 69-year-old male with lower limb areflexic weakness and gait ataxia without any COVID-19related preceding symptoms. His RT-PCR from a nasopharyngeal swab was positive for SARS-CoV-2. Electrophysiology tests were not performed. The patient improved spontaneously. In absence of nerve conduction tests, type of neuropathy could not be determined in both cases [67]. Chaumont et al. presented four patients (age range 52 to 72 years, all males), who presented with CNS symptoms along with quadriparesis after or during the weaning stage from the mechanical ventilator [68]. All patients had ARDS secondary to COVID-19 infection, and they developed neurological features after an interval of 12 to 20 days of initial COVID-19 symptoms. All patients had comorbid illnesses like diabetes mellitus in three, hypertension in two, urothelial cancer in one, and obstructive sleep apnoea in one patient. Three patients had evidence of demyelinating polyradiculoneuropathy whereas one patient had denervation in limbs suggestive of axonal neuropathy. One patient had asymmetrical neuropathy whereas the rest of the patients had symmetrical neuropathy. All patients had dysautonomia and action myoclonus, a feature not seen in critical-illness neuropathy. 


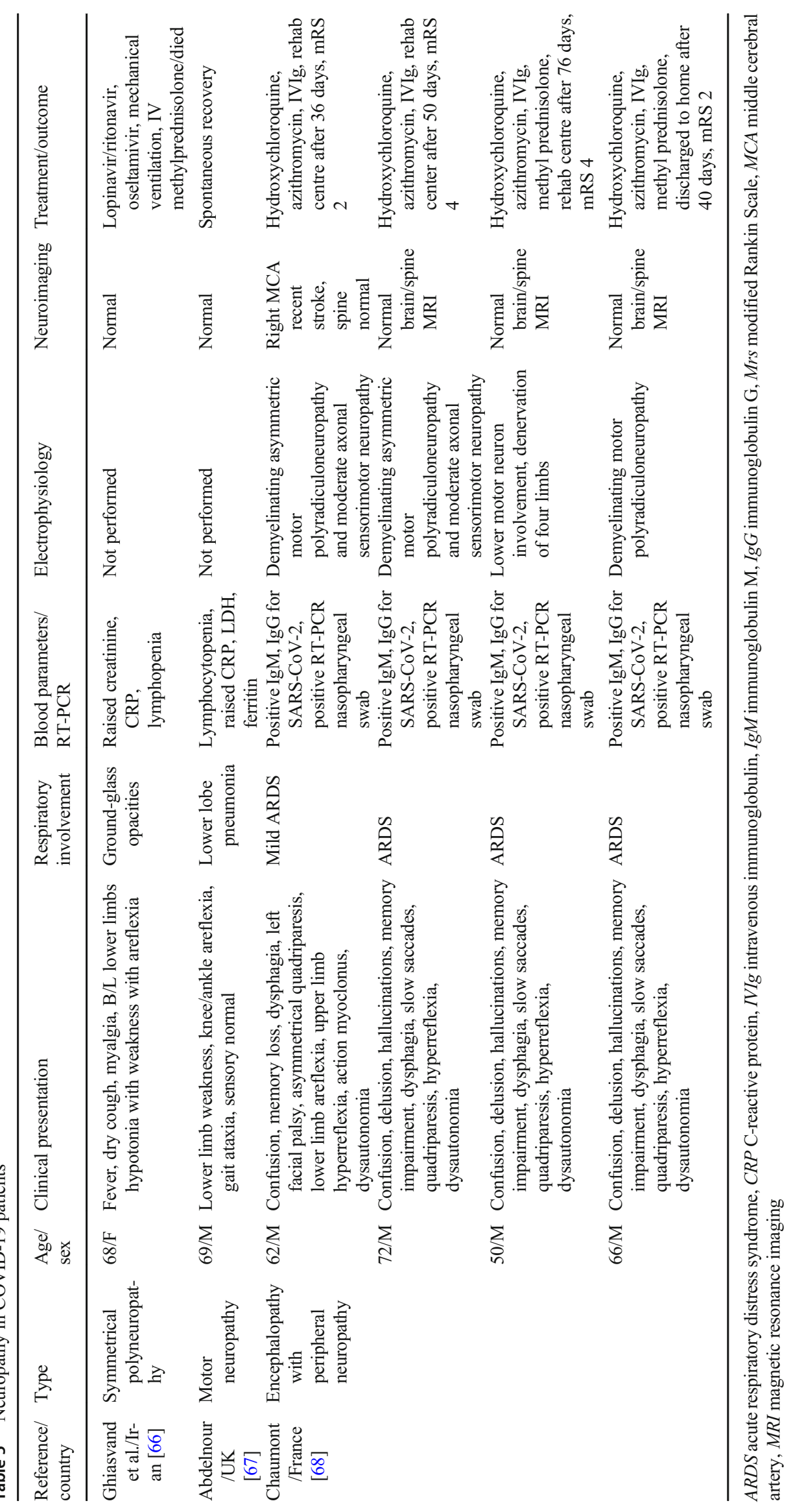




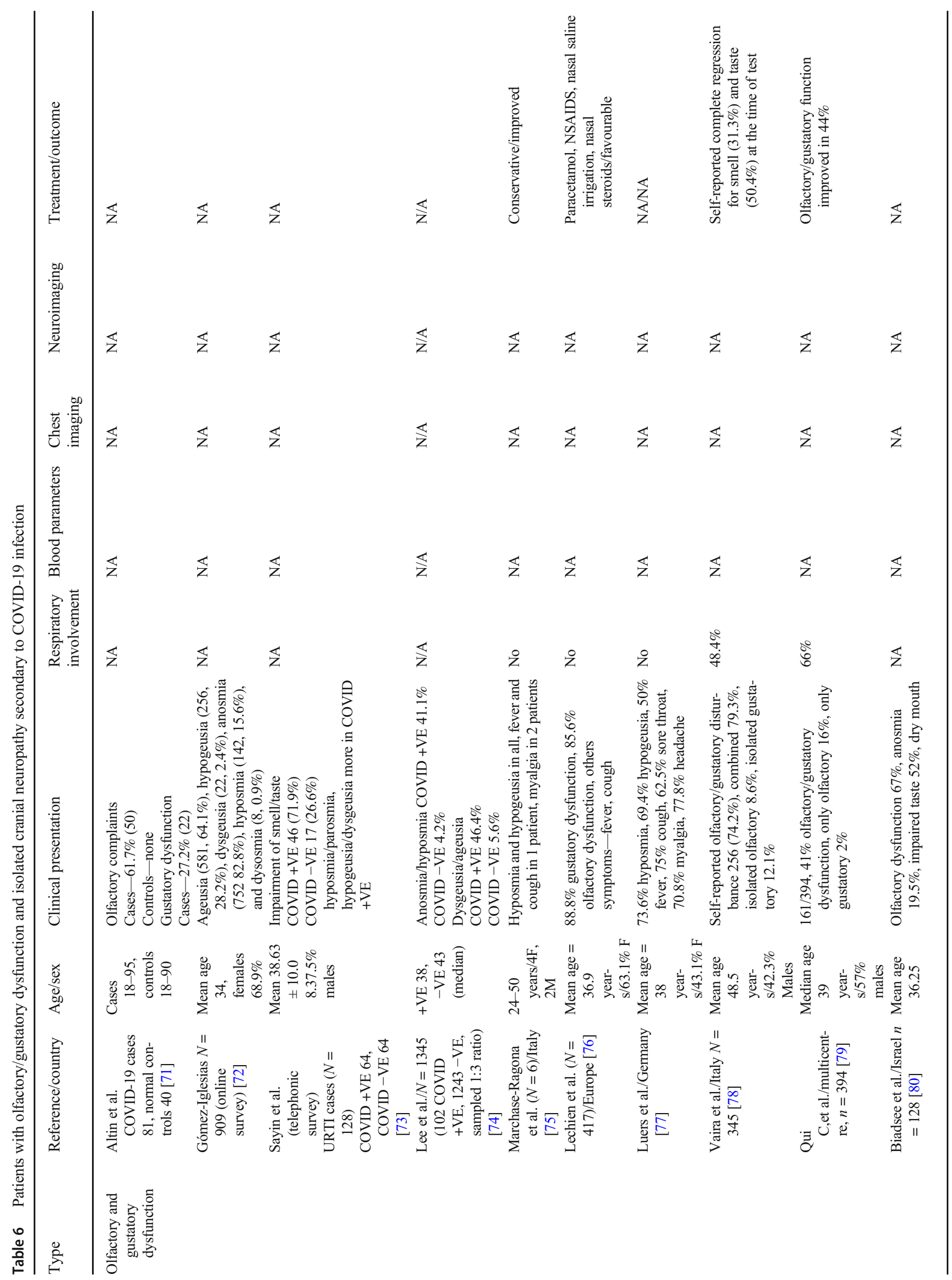




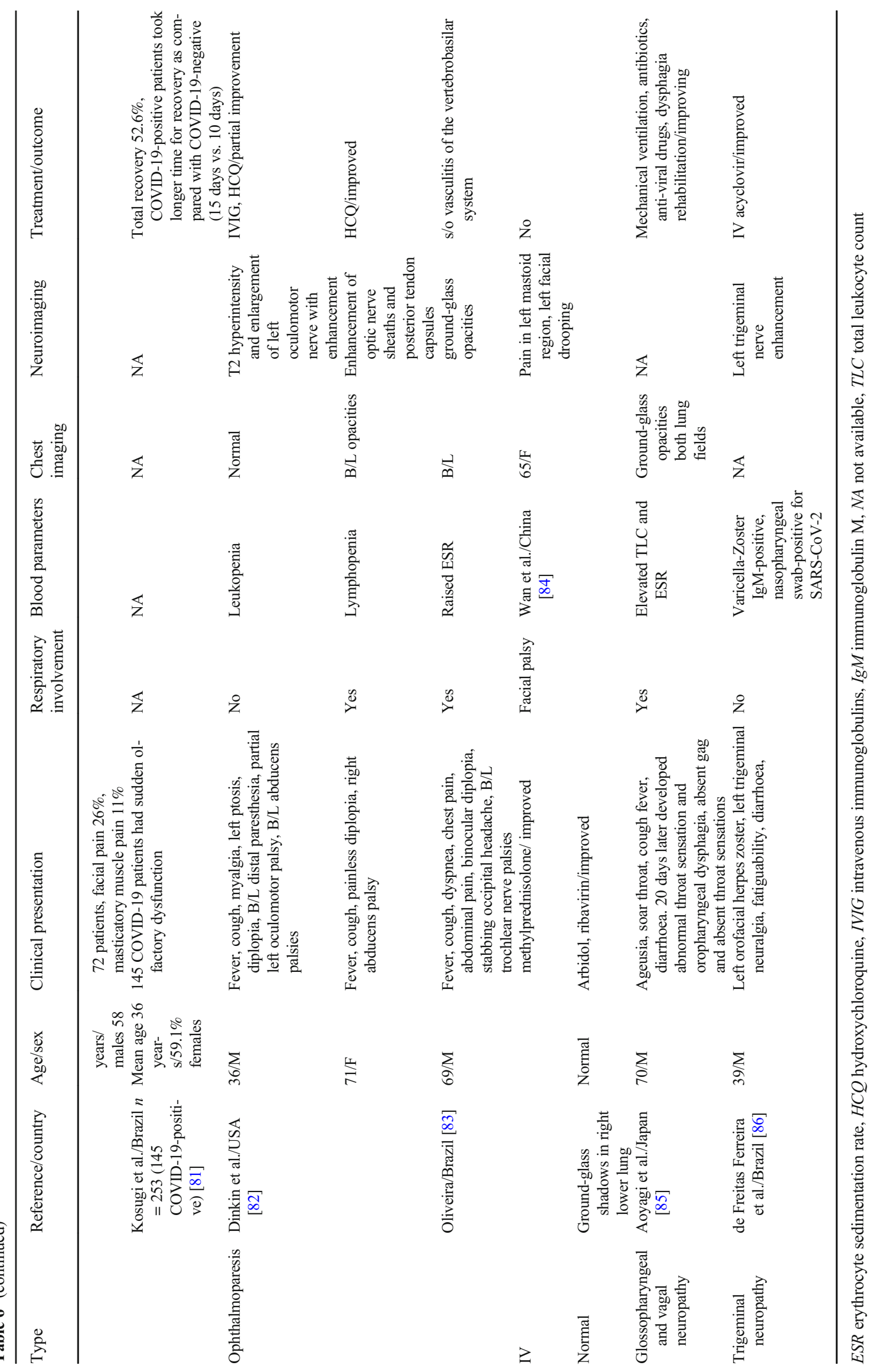




\section{Olfactory and gustatory dysfunction}

Olfactory and gustatory dysfunction is accepted as an early symptom of COVID-19 infection. In a review of 24 studies by Mehraeen et al., anosmia, hyposmia, ageusia, and dysgeusia was a presenting feature in majority of the studies [69]. They found anosmia to be the most common olfactory/gustatory symptom. They concluded that SARS-CoV-2 may infect neural and oral tissue and thereby present with olfactory and gustatory symptoms. Another review by Kang et al. (21 studies) had similar observations [70]. They found that the use of intranasal or oral steroids enhanced the recovery of COVID-19related olfactory/gustatory dysfunction [70]. We found 11 studies that specifically evaluated gustatory and olfactory functions in patients with COVID-19 infection [71-81]. Majority of patients had olfactory/gustatory dysfunction in addition to other symptoms like fever, cough, sore throat, and headache. The presence of olfactory/gustatory symptoms were not related to the severity of disease but related to the duration chemosensitive symptoms [78]. More patients were found to have chemosensitive dysfunction when examined with standard tests as compared with those who self-reported symptoms. By second week, 30 to 50\% patients reported regression of olfactory and gustatory symptoms [78].

In an autopsy study of two patients that died of COVID-19 infection (one had anosmia as early feature), authors found inflammation and axonal damage in the olfactory bulb explaining the olfactory symptoms [94]. In both cases, olfactory striae were normal. Other finding was perivascular leukocyte infiltration in the basal ganglia. The olfactory bulb edema has also been demonstrated on cranial MRI of patients with COVID-19 infection [95]. His anosmia and dysgeusia improved by 14 days and olfactory bulb edema also subsided on repeat MRI at 24 days of illness. In a study of 18 COVID19 patients who underwent Butanol threshold test and smell identification tests, the biopsies of the nasal mucosa revealed CD68 macrophages harbouring SARS-CoV-2 antigen in their stroma [96].

\section{Cranial neuropathy}

Various cranial neuropathies are described in patients with COVID-19 infection in relation to encephalopathy/ encephalitis or GBS. However, isolated cranial neuropathies have also been described. Dinkin et al. described a 36-year-old male with constitutional symptoms, diplopia secondary to left $3 \mathrm{rd}$, and bilateral 6th nerve palsy [82]. MRI showed hyperintensity on $\mathrm{T} 2$-weighted sequence and gadolinium enhancement of left 3rd cranial nerve. He showed partial improvement on intravenous immunoglobulin. Another 71year-old female presented with painless right 6 th cranial nerve palsy. She had gadolinium enhancement of optic nerve sheath.
She showed spontaneous improvement in diplopia. Oliveira RMC et al. reported a 69-year-old male with stabbing occipital pain and diplopia secondary to trochlear nerve palsy [83]. He had evidence of vertebrobasilar vasculitis that showed improvement on intravenous methylprednisolone. Another patient reported by Wan et al. had left facial palsy along with pain in left mastoid region. He improved with anti-viral drugs [84]. Glossopharyngeal, vagus, and trigeminal neuropathy (with Herpes Zoster co-infection) have also been described in patients with COVID-19 [85, 86]. All these patients with cranial neuropathies showed lung involvement secondary to COVID-19 infection.

\section{Patho-mechanism of nervous tissue involvement}

\section{Neuronal affinity and propagation}

ACE 2 is widely expressed on nervous tissue cells like neurons, astrocytes, and oligodendrocytes. Substantia nigra, ventricles, middle temporal gyrus, posterior cingulate cortex, and olfactory bulb express ACE-2 receptor in high concentrations. In addition, respiratory epithelium, lung parenchyma, vascular endothelium, kidney cells, and intestinal epithelium also express ACE-2 [97, 98]. Virus may gain entry to nervous tissue from vascular endothelial cells. Once inside the nerve cell, SARS-CoV-2 can alter the cellular transport function to facilitate its transmission from one neuron to another $[99,100]$.

Since SARS-CoV-2 is a respiratory virus, the virus particles have been shown in the CD 68 macrophages in the biopsy of nasal tissues from patients presenting with COVID-19related olfactory dysfunction [96]. Patients with olfactory dysfunction may have inflammation and edema of olfactory bulb $[94,95]$. In animal studies, it has been shown that coronavirus may utilize olfactory pathway to gain entry into central nervous system [101]. Neuronal changes have been detected in hypothalamus and cortex of SARS-CoV victims [102]. Retrograde transmission of the virus from peripheral nerve terminals through nerve synapses with the help of neural proteins dynein and kinesin have also been postulated [98]. SARS-CoV-2 RNA has also been demonstrated in the CSF [98].

\section{Mechanisms of involvement of peripheral nerves}

The mechanism of involvement of peripheral nervous system is not fully understood. It is mostly thought to be immunemediated. In patients with rapid evolution of GBS after the onset of COVID-19 symptoms, direct cytotoxic effects of virus on peripheral nerves is a postulated mechanism. GuillainBarrè syndrome (GBS) is usually considered an immunemediated disease of peripheral nerve myelin sheath or 
Schwann cells. The glycoproteins on the surface of the virus resemble with glycoconjugates in human nervous tissue [55]. The antibodies formed against the viral surface glycoproteins acts against the glycoconjugates on the neural tissue. This mechanism of nerve injury is famously known as "molecular mimicry". SARS-CoV-2 shares two hexapeptides with human shock proteins 90 and 60 . Both these proteins have immunogenic potentials, and they are among the 41 human proteins associated with Guillain-Barrè syndrome and chronic inflammatory demyelinating polyneuropathy [103]. The other neuropathies reported in patients with COVID-19 may also be secondary to immune-mediated mechanisms.

\section{Mechanism of muscle involvement}

The mechanism of myositis in COVID-19 infection is not fully understood. Skeletal muscles and other cells in the muscles like satellite cells, leukocytes, fibroblasts, and endothelial cells express ACE-2. Therefore, it is postulated that skeletal muscles are susceptible to direct muscle invasion by SARSCoV-2 [104]. Animal studies suggest that children are more likely to get affected due to their immature muscle cells [25]. Other possible mechanisms suggested are immune complex deposition in muscles, release of myotoxic cytokines, damage due to homology between viral antigens and human muscle cells, and adsorption of viral protein on muscle membranes leading to expression of viral antigens on myocyte surface. Whether these postulated mechanisms for COVID-19related myositis are also responsible for myalgia is also not known.

\section{Conclusion}

SARS-CoV-2 has a special affinity for the neural tissue. Olfactory and gustatory symptoms are accepted as an early manifestation of COVID-19 infection. Olfactory bulb inflammation and edema with axonal damage in patients with COVID-19 suggest an olfactory route entry of virus to involve the brain and other cranial nerves. The SARS-CoV-2 also involves peripheral nervous system. Myalgia is one of the common early symptoms of the disease. Guillain-Barrè syndrome and Miller-Fisher syndrome are increasingly being described in patients with preceding or concomitant COVID-19 disease. This points towards the involvement of peripheral nerves either by direct infection of nerves or by the mechanism of "molecular mimicry". There are also reports of myositis and rhabdomyositis secondary to COVID-19 disease. Since muscle also expresses ACE-2 receptors, direct muscle involvement by SARS-CoV-2 is postulated in addition to immune-mediated muscle damage.
Availability of data and material (data transparency) All data provided with the manuscript.

Authors' contributions VKP conceived and wrote the manuscript. RKG revised the manuscript. AG and NT wrote tables and collected data.

\section{Compliance with ethical standards}

Ethical approval The review does not require ethical clearance.

Conflict of interest The authors declare that they have no conflict of interests.

\section{References}

1. Cui J, Li F, Shi ZL (2019) Origin and evolution of pathogenic coronaviruses. Nat Rev Microbiol 17:181-192

2. Weiss SR, Navas-Martin S (2005) Coronavirus pathogenesis and the emerging pathogen severe acute respiratory syndrome coronavirus. Microbiol Mol Biol Rev 69:635-664

3. Perlman S, Netland J (2009) Coronaviruses post-SARS: update on replication and pathogenesis. Nat Rev Microbiol 7:439-450

4. Hilgenfeld R, Peiris M (2013) From SARS to MERS: 10 years of research on highly pathogenic human coronaviruses. Antivir Res 100:286-295

5. Alshukairi AN, Zheng J, Zhao J et al (2018) High prevalence of MERS-CoV infection in camel workers in Saudi Arabia. mBio 9: e01985-e01918

6. Natoli S, Oliveira V, Calabresi P, Maia, Pisani A (2020) Does SARS-Cov-2 invade the brain? Translational lessons from animal models. Eur J Neurol. https://doi.org/10.1111/ene.14277 Published on line April 25, 2020

7. Huang C, Wang Y, Li X, Ren L, Zhao J, Hu Y, Zhang L, Fan G, Xu J, Gu X, Cheng Z, Yu T, Xia J, Wei Y, Wu W, Xie X, Yin W, Li H, Liu M, Xiao Y, Gao H, Guo L, Xie J, Wang G, Jiang R, Gao Z, Jin Q, Wang J, Cao B (2020) Clinical features of patients infected with 2019 novel coronavirus in Wuhan, China. Lancet. 395:497-506. https://doi.org/10.1016/S0140-6736(20)30183-5

8. Xu XW, Wu XX, Jiang XG et al (2020). Clinical findings in a group of patients infected with the 2019 novel coronavirus (SARS-Cov-2) outside of Wuhan, China: retrospective case series [published correction appears in BMJ. 368:m792. BMJ 368: m606. Published 2020 Feb 19. https://doi.org/10.1136/bmj.m606.

9. Liu M, He P, Liu HG, Wang XJ, Li FJ, Chen S, Lin J, Chen P, Liu JH, Li CH (2020) Clinical characteristics of 30 medical workers infected with new coronavirus pneumonia. Zhonghua Jie $\mathrm{He} \mathrm{He}$ Hu Xi Za Zhi 43(3):209-214. https://doi.org/10.3760/cma.j.issn. 1001-0939.2020.03.014

10. Li LQ, Huang T, Wang YQ, Wang ZP, Liang Y, Huang TB, Zhang HY, Sun W, Wang Y (2020) COVID-19 patients' clinical characteristics, discharge rate, and fatality rate of meta-analysis. J Med Virol 92(6):577-583

11. Wang X, Liu W, Zhao J, Lu Y, Wang X, Yu C, Hu S, Shen N, Liu W, Sun Z, Li W (2020) Clinical characteristics of 80 hospitalized frontline medical workers infected with COVID-19 in Wuhan, China. J Hosp Infect S0195-6701(20):30194-30198. https://doi. org/10.1016/j.jhin.2020.04.019

12. Wei XS, Wang XR, Zhang JC, Yang WB, Ma WL, Yang BH, Jiang NC, Gao ZC, Shi HZ, Zhou Q (2020) A cluster of health care workers with COVID-19 pneumonia caused by SARS-CoV2. J Microbiol Immunol Infect S1684-1182(20):30107-30109. https://doi.org/10.1016/j.jmii.2020.04.013 
13. Lechien JR, Chiesa-Estomba CM, Place S, Van Laethem Y, Cabaraux P, Mat Q, Huet K, Plzak J, Horoi M, Hans S, Barillari MR (2020) Clinical and epidemiological characteristics of 1420 European patients with mild-to-moderate coronavirus disease 2019. J Intern Med 288:335-344. https://doi.org/10.1111/joim. 13089

14. Lai X, Wang M, Qin C, Tan L, Ran L, Chen D, Zhang H, Shang K, Xia C, Wang S, Xu S (2020) Coronavirus disease 2019 (COVID-2019) infection among health care workers and implications for prevention measures in a tertiary hospital in Wuhan, China. JAMA Netw Open 3(5):e209666. Published 2020 May 1. https://doi.org/10.1001/jamanetworkopen.2020.9666

15. Zhu J, Zhong Z, Ji P, Pang J, Zhang J, Zhao C (2020) Clinicopathological characteristics of 8697 patients with COVID-19 in China: a meta-analysis. Fam Med Community Health 8(2):e000406. https://doi.org/10.1136/fmch-2020-000406

16. Lapostolle F, Schneider E, Vianu I, Dollet G, Roche B, Berdah J, Michel J, Goix L, Chanzy E, Petrovic T, Adnet F (2020) Clinical features of 1487 COVID-19 patients with outpatient management in the Greater Paris: the COVID-call study. Intern Emerg Med 15: 1-5. https://doi.org/10.1007/s11739-020-02379-Z

17. Chen Y, Zhao M, Wu Y, Zang S (2020) Epidemiological analysis of the early 38 fatalities in Hubei, China, of the coronavirus disease 2019. J Glob Health 10(1):011004. https://doi.org/10.7189/ jogh-10-011004

18. Korkmaz MF, Türe E, Dorum BA, Kılıç ZB (2020) The epidemiological and clinical characteristics of 81 children with COVID-19 in a pandemic hospital in Turkey: an observational cohort study. J Korean Med Sci 35(25):e236. https://doi.org/10.3346/jkms.2020.35.e236

19. O'Reilly GM, Mitchell RD, Wu J et al (2020) Epidemiology and clinical features of emergency department patients with suspected COVID-19: results from the first month of the COVED Quality Improvement Project (COVED-2). Emerg Med Australas. https:// doi.org/10.1111/1742-6723.13573

20. Gaur A, Meena SK, Bairwa R, Meena D, Nanda R, Sharma SR, Rajawat GS (2020) Clinico-radiological presentation of COVID19 patients at a tertiary care center at Bhilwara Rajasthan, India. J Assoc Physicians India 68(7):29-33

21. Aggarwal A, Shrivastava A, Kumar A, Ali A (2020) Clinical and epidemiological features of SARS-CoV-2 patients in SARI ward of a tertiary care centre in New Delhi. J Assoc Physicians India 68(7):19-26

22. Borku Uysal B, Ikitimur H, Yavuzer S, Islamoglu MS, Cengiz M (2020) Case report: a COVID-19 patient presenting with mild rhabdomyolysis. Am J Trop Med Hyg 103:847-850. https://doi. org/10.4269/ajtmh.20-0583

23. Valente-Acosta B, Moreno-Sanchez F, Fueyo-Rodriguez O, Palomar-Lever A (2020) Rhabdomyolysis as an initial presentation in a patient diagnosed with COVID-19. BMJ Case Rep 13(6): e236719. https://doi.org/10.1136/bcr-2020-236719

24. Beydon M, Chevalier K, Al Tabaa O et al (2020) Myositis as a manifestation of SARS-CoV-2 [published online ahead of print, 2020 Apr 23]. Ann Rheum Dis:217573. https://doi.org/10.1136/ annrheumdis-2020-217573

25. Suwanwongse K, Shabarek N (2020) Rhabdomyolysis as a presentation of 2019 novel coronavirus disease. Cureus. 12(4):e7561. https://doi.org/10.7759/cureus.7561

26. Zhang Q, Shan KS, Minalyan A, O'Sullivan C, Nace T (2020) A rare presentation of coronavirus disease 2019 (COVID-19) induced viral myositis with subsequent rhabdomyolysis. Cureus. 12(5):e8074. https://doi.org/10.7759/cureus.8074

27. Jin M, Tong Q (2020) Rhabdomyolysis as Potential late complication associated with COVID-19. Emerg Infect Dis 26(7):16181620. https://doi.org/10.3201/eid2607.200445

28. Chan KH, Farouji I, Abu Hanoud A, Slim J (2020) Weakness and elevated creatinine kinase as the initial presentation of coronavirus disease 2019 (COVID-19). Am J Emerg Med 38(7):1548.e11548.e3. https://doi.org/10.1016/j.ajem.2020.05.015

29. Gefen AM, Palumbo N, Nathan SK, Singer PS, Castellanos-Reyes LJ, Sethna CB (2020) Pediatric COVID-19-associated rhabdomyolysis: a case report. Pediatr Nephrol 35(8):1517-1520. https:// doi.org/10.1007/s00467-020-04617-0

30. Ramaswamy SB, Govindarajan R (2020) COVID-19 in refractory myasthenia gravis-a case report of successful outcome. J Neuromuscul Dis 7(3):361-364. https://doi.org/10.3233/JND200520

31. Anand P, Slama MCC, Kaku M, Ong C, Cervantes-Arslanian AM, Zhou L, David WS, Guidon A (2020) COVID-19 in patients with myasthenia gravis. Muscle Nerve. https://doi.org/10.1002/ mus. 26918

32. Alberti P, Beretta S, Piatti M, Karantzoulis A, Piatti ML, Santoro P, Viganò M, Giovannelli G, Pirro F, Montisano DA, Appollonio I, Ferrarese C (2020) Guillain-Barré syndrome related to COVID19 infection. Neurol Neuroimmunol Neuroinflamm 7(4):e741. https://doi.org/10.1212/NXI.0000000000000741

33. Farzi MA, Ayromlou H, Jahanbakhsh N, Bavil PH, Janzadeh A, Shayan FK (2020) Guillain-Barré syndrome in a patient infected with SARS-CoV-2, a case. J Neuroimmunol 346:577294. https:// doi.org/10.1016/j.jneuroim.2020.577294

34. Hutchins KL, Jansen JH, Comer AD, Scheer RV, Zahn GS, Capps AE, Weaver LM, Koontz NA (2020) COVID-19-associated bifacial weakness with paresthesia subtype of Guillain-Barré syndrome. AJNR Am J Neuroradiol. https://doi.org/10.3174/ajnr.A6654

35. Webb S, Wallace VC, Martin-Lopez D, Yogarajah M (2020) Guillain-Barré syndrome following COVID-19: a newly emerging post-infectious complication. BMJ Case Rep 13(6):e236182. Published 2020 Jun 14. https://doi.org/10.1136/bcr-2020-236182

36. Kilinc D, van de Pasch S, Doets AY, Jacobs BC, van Vliet J, Garssen MPJ (2020) Guillain-Barré syndrome after SARS-CoV2 infection. https://doi.org/10.1111/ene.14398

37. Helbok R, Beer R, Löscher W, Boesch S, Reindl M, Hornung R, Schiefecker AJ, Deisenhammer F, Pfausler B (2020) GuillainBarré syndrome in a patient with antibodies against SARSCOV-2 [published online ahead of print, 2020 Jun 12]. Eur J Neurol 27:1754-1756. https://doi.org/10.1111/ene.14388

38. Sancho-Saldaña A, Lambea-Gil Á, Liesa JLC et al (2020) Guillain-Barré syndrome associated with leptomeningeal enhancement following SARS-CoV-2 infection. Clin Med (Lond). https://doi.org/10.7861/clinmed.2020-0213

39. Oguz-Akarsu E, Ozpar R, Mirzayev H, Acet-Ozturk NA, Hakyemez B, Ediger D, Karli N, Pandemic Study Team (2020) Guillain-Barré Syndrome in a patient with minimal symptoms of COVID-19 infection. Muscle Nerve 62:E54-E57. https://doi.org/ 10.1002/mus.26992

40. Lascano AM, Epiney JB, Coen M, Serratrice J, Bernard-Valnet R, Lalive PH, Kuntzer T, Hübers A (2020) SARS-CoV-2 and Guillain-Barré syndrome: AIDP variant with favorable outcome [published online ahead of print, 2020 Jun 1]. Eur J Neurol 27: 1751-1753. https://doi.org/10.1111/ene.14368

41. Chan JL, Ebadi H, Sarna JR (2020) Guillain-Barré syndrome with facial diplegia related to SARS-CoV-2 infection [published online ahead of print, 2020 May 29]. Can J Neurol Sci:1-3. https://doi. org/10.1017/cjn.2020.106

42. Riva N, Russo T, Falzone YM et al (2020) Post-infectious GuillainBarré syndrome related to SARS-CoV-2 infection: a case report. J Neurol:1-3. https://doi.org/10.1007/s00415-020-09907-z

43. Zhao H, Shen D, Zhou H, Liu J, Chen S (2020) Guillain-Barré syndrome associated with SARS-CoV-2 infection: causality or coincidence? Lancet Neurol 19(5):383-384

44. Scheidl E, Canseco DD, Hadji-Naumov A, Bereznai B (2020) Guillain-Barré syndrome during SARS-CoV-2 pandemic: a case 
report and review of recent literature. J Peripher Nerv Syst 25(2): 204-207. https://doi.org/10.1111/jns.12382

45. Ottaviani D, Boso F, Tranquillini E, Gapeni I, Pedrotti G, Cozzio S, Guarrera GM, Giometto B (2020) Early Guillain-Barré syndrome in coronavirus disease 2019 (COVID-19): a case report from an Italian COVID-hospital. Neurol Sci 41(6):1351-1354. https://doi.org/10.1007/s10072-020-04449-8

46. Juliao Caamaño DS, Alonso Beato R (2020) Facial diplegia, a possible atypical variant of Guillain-Barré Syndrome as a rare neurological complication of SARS-CoV-2. J Clin Neurosci 77: 230-232. https://doi.org/10.1016/j.jocn.2020.05.016

47. Chan M, Han SC, Kelly S, Tamimi M, Giglio B, Lewis A (2020) A case series of Guillain-Barré Syndrome following Covid-19 infection in New York. Neurol Clin Pract. https://doi.org/10. 1212/CPJ.0000000000000880

48. Bigaut K, Mallaret M, Baloglu S, Nemoz B, Morand P, Baicry F, Godon A, Voulleminot P, Kremer L, Chanson JB, de Seze J (2020) Guillain-Barré syndrome related to SARS-CoV-2 infection. Neurol Neuroimmunol Neuroinflamm 7(5):e785. https:// doi.org/10.1212/NXI.0000000000000785

49. Assini A, Benedetti L, Silvia DM, Erika S, Sette MD (2020) Two different clinical manifestation of Covid-19 related Guillain-Barrè syndrome highly responsive to intravenous immunoglobulins: two Italian cases. Research Square. https://doi.org/10.21203/rs.3. rs-30354/v1

50. Gigli GL, Bax F, Marini A, Pellitteri G, Scalise A, Surcinelli A, Valente M (2020) Guillain-Barré syndrome in the COVID-19 era: just an occasional cluster? J Neurol:1-3. https://doi.org/10.1007/ s00415-020-09911-3

51. Arnaud S, Budowski C, Ng Wing Tin S, Degos B (2020) Post SARS-CoV-2 Guillain-Barré syndrome. Clin Neurophysiol 131(7):1652-1654. https://doi.org/10.1016/j.clinph.2020.05.003

52. Rana S, Lima AA, Chandra R, Valeriano J, Desai T, Freiberg W, Small G (2020) Novel coronavirus (COVID-19)-associated Guillain-Barré syndrome: case report. J Clin Neuromuscul Dis 21(4):240-242. https://doi.org/10.1097/CND. 0000000000000309

53. Su XW, Palka SV, Rao RR, Chen FS, Brackney CR, Cambi F (2020) SARS-CoV-2-associated Guillain-Barré syndrome with dysautonomia. Muscle Nerve 62:E48-E49. https://doi.org/10. 1002/mus.26988

54. Pfefferkorn T, Dabitz R, von Wernitz-Keibel T, Aufenanger J, Nowak-Machen M, Janssen H (2020) Acute polyradiculoneuritis with locked-in syndrome in a patient with Covid-19. J Neurol 267(7):1883-1884. https://doi.org/10.1007/s00415-020-09897-y

55. Sedaghat Z, Karimi N (2020) Guillain Barre syndrome associated with COVID-19 infection: a case report. J Clin Neurosci 76:233235. https://doi.org/10.1016/j.jocn.2020.04.062

56. Toscano G, Palmerini F, Ravaglia S, Ruiz L, Invernizzi P, Cuzzoni MG, Franciotta D, Baldanti F, Daturi R, Postorino P, Cavallini A, Micieli G (2020) Guillain-Barré syndrome associated with SARS-CoV-2. N Engl J Med 382(26):2574-2576. https:// doi.org/10.1056/NEJMc2009191

57. Virani A, Rabold E, Hanson T, Haag A, Elrufay R, Cheema T, Balaan M, Bhanot N (2020) Guillain-Barré syndrome associated with SARS-CoV-2 infection [published online ahead of print, 2020 Apr 18]. IDCases. 20:e00771. https://doi.org/10.1016/j. idcr.2020.e00771

58. Padroni M, Mastrangelo V, Asioli GM, Pavolucci L, AbuRumeileh S, Piscaglia MG, Querzani P, Callegarini C, Foschi M (2020) Guillain-Barré syndrome following COVID-19: new infection, old complication? J Neurol 267(7):1877-1879. https:// doi.org/10.1007/s00415-020-09849-6

59. Coen M, Jeanson G, Culebras Almeida LA et al (2020) GuillainBarré syndrome as a complication of SARS-CoV-2 infection.
Brain Behav Immun S0889-1591(20):30698-X. https://doi.org/ 10.1016/j.bbi.2020.04.074

60. El Otmani H, El Moutawakil B, Rafai MA et al (2020) Covid-19 and Guillain-Barré syndrome: more than a coincidence! Rev Neurol (Paris) 176(6):518-519. https://doi.org/10.1016/j.neurol. 2020.04.007

61. Marta-Enguita J, Rubio-Baines I, Gastón-Zubimendi I (2020) Fatal Guillain-Barre syndrome after infection with SARS-CoV2. Síndrome de Guillain-Barré fatal tras infección por el virus SARS-CoV-2. Neurologia. 35(4):265-267. https://doi.org/10. 1016/j.nrl.2020.04.004

62. Reyes-Bueno JA, García-Trujillo L, Urbaneja P, Ciano-Petersen NL, Postigo-Pozo MJ, Martínez-Tomás C, Serrano-Castro PJ (2020) Miller-Fisher syndrome after SARS-CoV-2 infection. Eur J Neurol 27:1759-1761. https://doi.org/10.1111/ene.14383

63. Fernández-Domínguez J, Ameijide-Sanluis E, García-Cabo C, García-Rodríguez R, Mateos V (2020) Miller-Fisher-like syndrome related to SARS-CoV-2 infection (COVID 19). J Neurol: 1-2. https://doi.org/10.1007/s00415-020-09912-2

64. Lantos JE, Strauss SB, Lin E (2020) COVID-19-Associated Miller Fisher syndrome: MRI findings. AJNR Am J Neuroradiol 41:1184-1186. https://doi.org/10.3174/ajnr.A6609

65. Gutiérrez-Ortiz C, Méndez A, Rodrigo-Rey S et al (2020) Miller Fisher syndrome and polyneuritis cranialis in COVID-19. Neurology. 95:e601-e605. https://doi.org/10.1212/WNL. 000000000009619

66. Ghiasvand F, Ghadimi M, Ghadimi F, Safarpour S, Hosseinzadeh R, SeyedAlinaghi SA (2020) Symmetrical polyneuropathy in coronavirus disease 2019 (COVID-19). Idcases. 21:e00815. https:// doi.org/10.1016/j.idcr.2020.e00815

67. Abdelnour L, Eltahir Abdalla M, Babiker S (2020) COVID 19 infection presenting as motor peripheral neuropathy. J Formos Med Assoc 119(6):1119-1120. https://doi.org/10.1016/j.jfma. 2020.04.024

68. Chaumont H, San-Galli A, Martino F, Couratier C, Joguet G, Carles M, Roze E, Lannuzel A (2020) Mixed central and peripheral nervous system disorder in severe SARS-Cov-2 infection:17. https://doi.org/10.1007/s00415-020-09986-y

69. Mehraeen E, Behnezhad F, Salehi MA et al (2020) Olfactory and gustatory dysfunctions due to the coronavirus disease (COVID19): a review of current evidence. Eur Arch Otorhinolaryngol:1-6. https://doi.org/10.1007/s00405-020-06120-6

70. Kang YJ, Cho JH, Lee MH, Kim YJ, Park CS (2020) The diagnostic value of detecting sudden smell loss among asymptomatic COVID-19 patients in early stage: the possible early sign of COVID-19. Auris Nasus Larynx S0385-8146(20):30140-30141. https://doi.org/10.1016/j.anl.2020.05.020t

71. Altin F, Cingi C, Uzun T, Bal C (2020) Olfactory and gustatory abnormalities in COVID-19 cases. Eur Arch Otorhinolaryngol:17. https://doi.org/10.1007/s00405-020-06155-9

72. Gómez-Iglesias P, Porta-Etessam J, Montalvo T, Valls-Carbó A, Gajate V, Matías-Guiu JA, Parejo-Carbonell B, González-García N, Ezpeleta D, Láinez JM, Matías-Guiu J (2020) An online observational study of patients with olfactory and gustory alterations secondary to SARS-CoV-2 infection. Front Public Health 8:243. https://doi.org/10.3389/fpubh.2020.00243

73. Sayin İ, Yaşar KK, Yazici ZM (2020) Taste and smell impairment in COVID-19: an AAO-HNS Anosmia Reporting Tool-Based Comparative Study. Otolaryngol Head Neck Surg 194599820931820. https://doi.org/10.1177/0194599820931820

74. Lee DJ, Lockwood J, Das P, Wang R, Grinspun E, Lee JM (2020) Self-reported anosmia and dysgeusia as key symptoms of coronavirus disease 2019. CJEM:1-8. https://doi.org/10.1017/cem.2020.420

75. Marchese-Ragona R, Ottaviano G, Nicolai P, Vianello A, Carecchio M Sudden hyposmia as a prevalent symptom of 
COVID-19 infection. medRxiv. https://doi.org/10.1101/2020.04. 06.20045393

76. Lechien JR, Chiesa-Estomba CM, De Siati DR, Horoi M, Le Bon SD, Rodriguez A, Dequanter D, Blecic S, El Afia F, Distinguin L, Chekkoury-Idrissi Y (2020) Olfactory and gustatory dysfunctions as a clinical presentation of mild-to-moderate forms of the coronavirus disease (COVID-19): a multicenter European study. Eur Arch Otorhinolaryngol 277:1-11. https://doi.org/10.1007/s00405020-05965-1

77. Luers JC, Rokohl AC, Loreck N, Wawer Matos PA, Augustin M, Dewald F, Klein F, Lehmann C, Heindl LM (2020) Olfactory and gustatory dysfunction in Coronavirus disease 19 (COVID-19). Clin Infect Dis ciaa525. https://doi.org/10.1093/cid/ciaa525

78. Vaira LA, Salzano G, Deiana G, De Riu G (2020) Anosmia and ageusia: common findings in COVID-19 patients. Laryngoscope. 130(7):1787. https://doi.org/10.1002/lary.28692

79. Qiu C, Cui C, Hautefort C et al (2020) Olfactory and gustatory dysfunction as an early identifier of COVID-19 in adults and children: an international multicenter study. Otolaryngol Head Neck Surg 194599820934376. https://doi.org/10.1177/ 0194599820934376

80. Biadsee A, Biadsee A, Kassem F et al (2020) Olfactory and oral manifestations of COVID-19: sex-related symptoms-a potential pathway to early diagnosis. Otolaryngol Head Neck Surg 194599820934380. https://doi.org/10.1177/0194599820934380

81. Kosugi EM, Lavinsky J, Romano FR, Fornazieri MA, LuzMatsumoto GR, Lessa MM, Piltcher OB, Sant'Anna GD (2020) Incomplete and late recovery of sudden olfactory dysfunction in COVID-19. Braz J Otorhinolaryngol S1808-8694(20):3005930058. https://doi.org/10.1016/j.bjorl.2020.05.001

82. Dinkin M, Gao V, Kahan J, Bobker S, Simonetto M, Wechsler P, Harpe J, Greer C, Mints G, Salama G, Tsiouris AJ (2020) COVID19 presenting with ophthalmoparesis from cranial nerve palsy. Neurology. 95:221-223. https://doi.org/10.1212/WNL. 0000000000009700

83. Oliveira RMC, Santos DH, Olivetti BC, Takahashi JT (2020) Bilateral trochlear nerve palsy due to cerebral vasculitis related to COVID-19 infection. Arq Neuropsiquiatr 78(6):385-386. https://doi.org/10.1590/0004-282x20200052

84. Wan Y, Cao S, Fang Q, Wang M, Huang Y (2020) Coronavirus disease 2019 complicated with Bell's palsy: a case report. Research Square. https://doi.org/10.21203/rs.3.rs-23216/v1

85. Aoyagi Y, Ohashi M, Funahashi R, Otaka Y, Saitoh E (2020) Oropharyngeal dysphagia and aspiration pneumonia following Coronavirus disease 2019: a case report. Dysphagia. 1-4:545548. https://doi.org/10.1007/s00455-020-10140-z

86. de Freitas Ferreira ACA, Romão TT, SIlva Macedo Y, Pupe C, Nascimento OJ (2020) COVID-19 and herpes zoster co-infection presenting with trigeminal neuropathy. Eur J Neurol 27:1748 1750. https://doi.org/10.1111/ene.14361

87. Zhang J, Wang X, Jia X, Li J, Hu K, Chen G, Wei J, Gong Z, Zhou C, Yu H, Yu M, Lei H, Cheng F, Zhang B, Xu Y, Wang G, Dong W (2020) Risk factors for disease severity, unimprovement, and mortality in COVID-19 patients in Wuhan, China. Clin Microbiol Infect 26(6):767-772. https://doi.org/10.1016/j.cmi.2020.04.012

88. Peyronnet V, Sibiude J, Deruelle P, Huissoud C, Lescure X, Lucet J-C, Mandelbrot L, Nisand I, Vayssière C, Yazpandanah Y, Luton D, Picone O (2020) SARS-CoV-2 infection during pregnancy. Information and proposal of management care. CNGOF. Gynecol Obstet Fertil Senol 48(5):436-443. https://doi.org/10. 1016/j.gofs.2020.03.014

89. Zhang T, Sun LX, Feng RE (2020) Comparison of clinical and pathological features between severe acute respiratory syndrome and coronavirus disease 2019. Zhonghua Jie He He Hu Xi Za Zhi 43(6):496-502. https://doi.org/10.3760/cma.j.cn11214720200311-00312
90. Shah SJ, Barish PN, Prasad PA et al (2020) Clinical features, diagnostics, and outcomes of patients presenting with acute respiratory illness: a comparison of patients with and without COVID19. Preprint. medRxiv. https://doi.org/10.1101/2020.05.02. 20082461

91. Corsini Campioli C, Cano Cevallos E, Assi M, Patel R, Binnicker MJ, O'Horo JC (2020) Clinical predictors and timing of cessation of viral RNA shedding in patients with COVID-19. J Clin Virol 130:104577. https://doi.org/10.1016/j.jcv.2020.104577

92. Madia F, Merico B, Primiano G, Cutuli SL, De Pascale G, Servidei S (2020) Acute myopathic quadriplegia in COVID-19 patients in the intensive care unit. Neurology. Advance online publication. https://doi.org/10.1212/WNL.0000000000010280

93. Morley JE, Kalantar-Zadeh K, Anker SD (2020) COVID-19: a major cause of cachexia and sarcopenia? J Cachexia Sarcopenia Muscle 11:863-865. https://doi.org/10.1002/jcsm.12589. Advance online publication

94. Kirschenmbaum D, Imbach LL, Ulrich S, Rushing EJ, Keller E, Reimann RR, Frauenknecht KBM, Lichtblau M, Witt M, Thomas H, Steiger P, Adriano A, Frontzek K (2020) Inflammatory olfactory neuropathy in two patients with Covid-19. Research Square. https://doi.org/10.21203/rs.3.rs-34001/v1

95. Laurendon T, Radulesco T, Mugnier J, Gérault M, Chagnaud C, el Ahmadi AA, Varoquaux A (2020) Bilateral transient olfactory bulbs edema during COVID-19-related anosmia. Neurology. 95: 224-225. https://doi.org/10.1212/wnl.0000000000009850

96. Chung TW, Sridhar S, Zhang AJ et al (2020) Olfactory dysfunction in Coronavirus disease 2019 patients: observational cohort study and systematic review. Open Forum Infect Dis 7(6): ofaa199. https://doi.org/10.1093/ofid/ofaa199

97. Hoffmann M, Kleine-Weber H, Schroeder S et al (2020) SARSCoV-2 cell entry depends on ACE2 and TMPRSS2 and is blocked by a clinically proven protease inhibitor. Cell 181(2):271-280.e8. https://doi.org/10.1016/j.cell.2020.02.052

98. Conde Cardona G, Quintana Pájaro LD, Quintero Marzola ID, Ramos Villegas Y, Moscote Salazar LR (2020) Neurotropism of SARS-CoV 2: mechanisms and manifestations. J Neurol Sci 412: 116824. https://doi.org/10.1016/j.jns.2020.116824

99. Bohmwald K, Gálvez NMS, Ríos M, Kalergis AM (2018) Neurologic alterations due to respiratory virus infections. Front Cell Neurosci 12:386. https://doi.org/10.3389/fncel.2018.00386

100. Dubé M, Le Coupanec A, Wong AHM, Rini JM, Desforges M, Talbot PJ (2018) Axonal transport enables neuron-to-neuron propagation of human Coronavirus OC43. J Virol 92(17):e00404 e00418. https://doi.org/10.1128/JVI.00404-18

101. Netland J, Meyerholz DK, Moore S, Cassell M, Perlman S (2008) Severe acute respiratory syndrome coronavirus infection causes neuronal death in the absence of encephalitis in mice transgenic for human ACE2. J Virol 82(15):7264-7275

102. Gu J, Gong E, Zhang B, Zheng J, Gao Z, Zhong Y, Zou W, Zhan J, Wang S, Xie Z, Zhuang H, Wu B, Zhong H, Shao H, Fang W, Gao D, Pei F, Li X, He Z, Xu D, Shi X, Anderson VM, Leong ASY (2005) Multiple organ infection and the pathogenesis of SARS. J Exp Med 202(3):415-424

103. Lucchese G, Flöel A (2020) SARS-CoV-2 and Guillain-Barré syndrome: molecular mimicry with human heat shock proteins as potential pathogenic mechanism. Cell Stress Chaperones:1-5. https://doi.org/10.1007/s12192-020-01145-6

104. Ferrandi PJ, Alway SE, Mohamed JS (2020) The interaction between SARS-CoV-2 and ACE2 may have consequences for skeletal muscle viral susceptibility and myopathies. J Appl Physiol (1985). https://doi.org/10.1152/japplphysiol.00321.2020

Publisher's note Springer Nature remains neutral with regard to jurisdictional claims in published maps and institutional affiliations. 